\title{
Improving the Human Condition Is A Life's Journey
}

\author{
* Dr. Allan G. Richards \\ * University of Kentucky, USA
}

Improving the human condition requires us first to understand and to address the issues that impact each of us. Because of our perceived differences, conflicts are inevitable, they are a part of our lives, but it is incumbent on all of us to do our part to ameliorate them. Whether they know it or not, the above students are developing the knowledge and skills to ameliorate problems that could cause conflicts by finding their voice, making contributions to society, and learning to effectively communicate through the fastmoving technology platforms. Using the United States as an example of how unresolved conflicts can mushroom and pose existential threats to the advancement of the human condition is intended to suggest that if it is happening here in the US, it can and is happening all over the world where there are conflicts between races, genders, religious persuasions, individuals, groups, communities, and countries -China, Russia, Syria, etc. When given opportunities, each person will encounter issues affecting them, challenges they want to overcome, problems they want to solve and education through the arts can provide students these opportunities. Improving the human condition gives us hope for a better future and hope for a better future is dependent on how well educators do their jobs preparing students to be good citizens of the global community.

Human Condition, Improvement, Art Education. 
بحوث في التربية الفنية والفنون، المجلد (21)، العدد 2

When I decided to pursue a career in education as my life's journey it became clear to me that improving the human condition is paramount to my mission. What I have learned so far on this journey is that conflicts are at the center of preventing improvement of the human condition. Improving the human condition is about ensuring human rights, equality, and justice for all human beings regardless of their race, color, or creed, or their status in life, or in what country they were born. Often time these differences challenge our humanity. Education through the arts offers us opportunities to ameliorate the worst instincts of our human nature to resort to anti-social behaviors that could lead to exploitation and violence against one another. Ameliorating the worst instincts of our human nature is about developing the instinct to contemplate grace and consequences. Grace is about forgiveness and consequences are about taking responsibility for the wrongs we have committed and make the necessary changes to do better. Life is about constant changes, challenges and decision making, even though we might not be conscious of them, but we can grow from the mistakes we make along this life's journey and hopefully what we learn from these mistakes is how to improve the human condition for all.

There is much that we can learn from our ancestors about grace and consequences and the power of education to improve the human condition. The challenges early humans faced as they inhabited a hostile planet were tremendous, but what is clear is that they worked relentlessly to educate themselves to solve the problems they encountered by recognizing the mistakes made, and the resolutions of their problems led to the birth and advancement of different civilizations such as the Incan, Aztec, Roman, Persian, Greek, Maya, Ancient Egyptian, and others. Today we are the beneficiaries of these civilizations that made it possible for "modern civilizations" because of the infrastructure our ancestors left us, and it made me believe that improving the human condition will lead to the advancement of humanity. But this will require the resolution of conflicts between one another, nation states, and between countries if we are going to leave a progressive global community for future generations
White supremacy ideology is the belief that White people are superior to those of other races and thus have the right to dominate them (Vander Zanden, 1959). A culture that is founded on white supremacy ideology would go to any lengths to shape norms, values, beliefs and standards to advantage White people and oppress people of color. Slavery and colonialism, grounded in White supremacy ideology, gave the United States the Civil War (1861-1865) and Jim Crow laws (Post Civil War until 1968) that seem to continue to brutally discriminate against people of color resulting in inequality and injustice, and violation of their civil rights. The trauma from these experiences continue to ripple through the US society as witness the rise in violence against Asian American and Pacific Islanders, the murder of George Floyd and Breonna Taylor and countless others, the January 6, 2021 insurrection that took place in the US Capital, and the disproportionate impact the COVID-19 pandemic is having on people of color. Based on the current situation, it could be concluded that White supremacy ideology continues to prevent America from moving forward to form "A More Perfect Union."

It is reported that Leroy Eldridge Cleaver, an American writer, a political activist, and an early leader of the Black Panther Party, said "You either have to be part of the solution, or you're going to be part of the problem." Not taking responsibility for the atrocities that continues based on White supremacy ideology makes us compliant in maintaining the status quo. Perhaps this is why Ken Robinson (2011), professor, British author, speaker and international advisor on education in the arts to governments, non-profits, and education and arts bodies, affirms that we created the human world we now live in and we can recreate it from our creativity, imagination, innovation, and new ideas. Recreating a new human world everyone must want to solve the problem of hate and other concealed idiosyncrasies that cause conflicts. Nelson Mandela, Former President of South Africa and first Black president, said "Education is the most powerful weapon which you can use to change the world." Education may be the most powerful weapon for 
بحوث في التربية الفنية والفنون، المجلد (21)، العدد 2

change but if it does not provide opportunities to inculcate and develop the instinct of grace and consequences, we would be furthering the status quo. Building knowledge to understand the past and developing skills to ameliorate hatred of others must be the focus of education for it to recreate the human world that improves the human condition and advance civilization for the next generation A failure to plan, as a society, and we will continue to experience the problems of hate, bigotry, and the dehumanization of fellow human beings because of their color, customs, and traditions (Hamid, 2017). Richards and Willis (2020), visual arts educators, in their book -Global Consciousness through the Arts: A Passport for Students and Teachers, say "public schools are a microcosm of the global community, and building global consciousness through the arts means starting right now to prepare PK-12 students and teachers alike for a diverse population that will be different from anything they have seen before. Global Consciousness through the Arts: A Passport for Students and Teachers focuses on historical and current events that have impleaded the improvement of the human condition for centuries. These events are intended to expose students and teachers to their own biases and issues with otherness so teachers can find a space and a forum for students to reflect and to address their perceived biases. Global Consciousness, Foundational Tools, Success in an International Community, and Artistic Voice are four themes in the book that are expanded on in 16 chapters. This book also has a rich diversity of content materials that are provided by a 305 -Page Online Ancillary with lesson plans and different stories from 53 international arts educators and artists from 14 different countries.

Global Consciousness through the Arts: A Passport for Students and Teachers also provides different pedagogical approaches to deliver its arts content, but I would like to focus on one for this paper. Current Event, Conceptual Art, and Project-Based learning is the pedagogy strategy that is articulated most prominently in the book and is intended to provide students opportunities to develop the requisite knowledge and skills to ameliorate conflicts and improve the human condition. Current events are about making students aware of what is happening around them in other words, educate students about the problems at hand and their historical contexts. Conceptual art is a phrase drawn from studio art with the intent to provide students the freedom to imagine and articulate (visually, verbally, and in narrative form) possible solutions to the problems they have encountered or perceived. Project-based learning is intended to help students develop the skills they need to effectively interact with others who may not share their worldviews. These precepts allow me to assign chapters and ancillaries from the book for my Art Education students to analyze and come up with a theoretical construct that they have expressed in a visual image and narrative suggesting how they arrived at their conclusion.

Below are three examples of how some Art education students in my class at the University of Kentucky in the US responded visually and narratively to assigned chapters from the Global Consciousness through the Arts: A Passport for Students and Teachers book. Names of students whose work are selected for this article are withheld to protect their identities but give them credit for their work should they wish to claim it by each revealing their identity. The first image and narrative below are created from Chapter 3-Finding One's Voice. The image is from a student who is multiracial, and she is concerned about how others perceive her and how she perceived herself. This is an internal conflict that is impacting this student in a negative way and might be preventing her from improving her humanity and the human conditions in general. The second example comes from another student responding to Chapter 4 --Contribution. Helping hands and the idea of community bonding is the concept that this student imagined that would highlight the contributions of those who are not recognized because of otherness. The third image is one that is created from the analysis of Chapter 6 -Media, Materials, and Techniques. This student created a computer graphic image and post a narrative with it to articulate that students need to be proficient in new media, materials and techniques as they prepare to face an uncertain future that will require adept skills to communicate. 


\section{Students' Artworks}

\section{Chapter 3: Finding One's Voice}

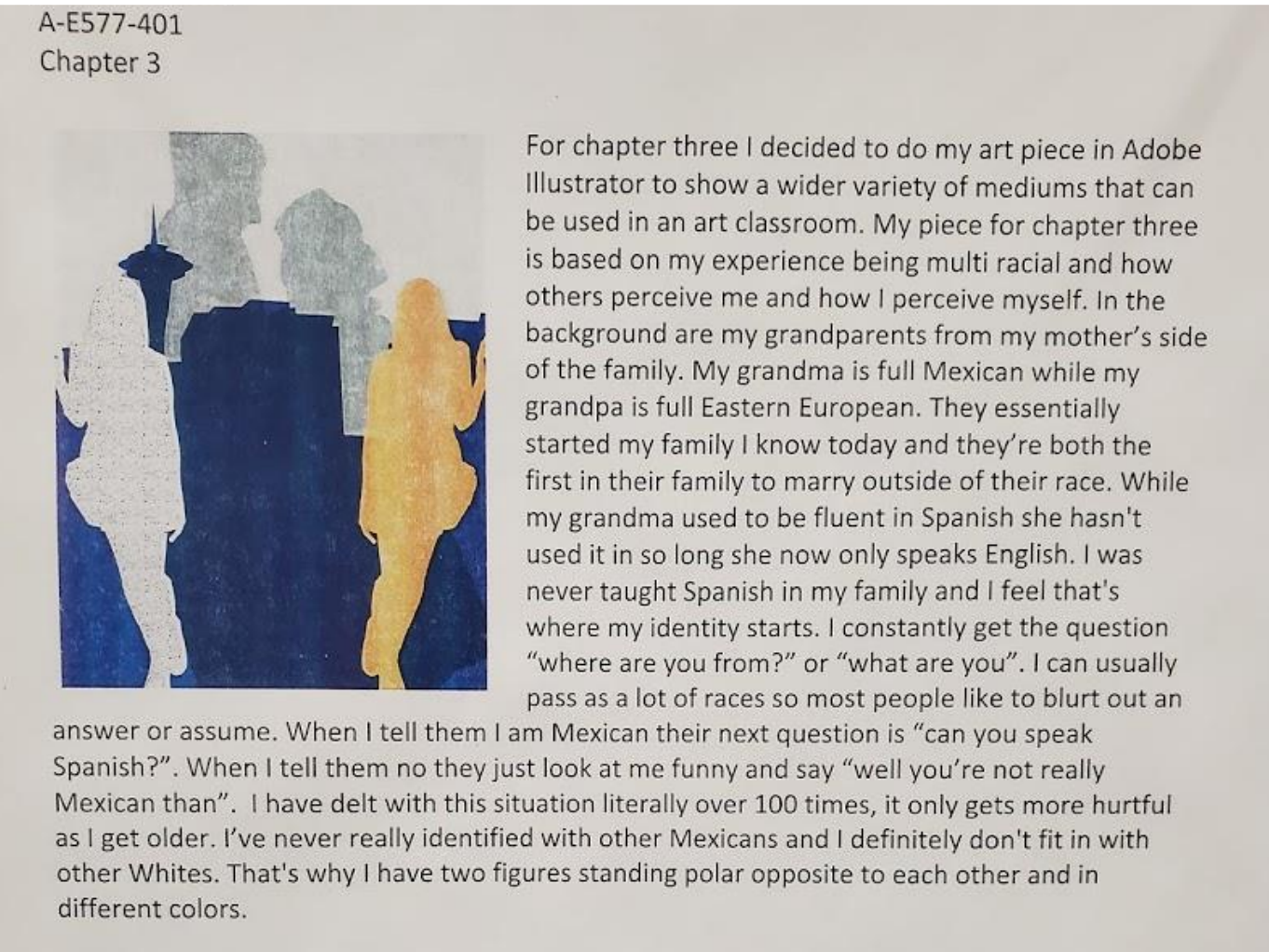

\section{Chapter 4: Contributions}

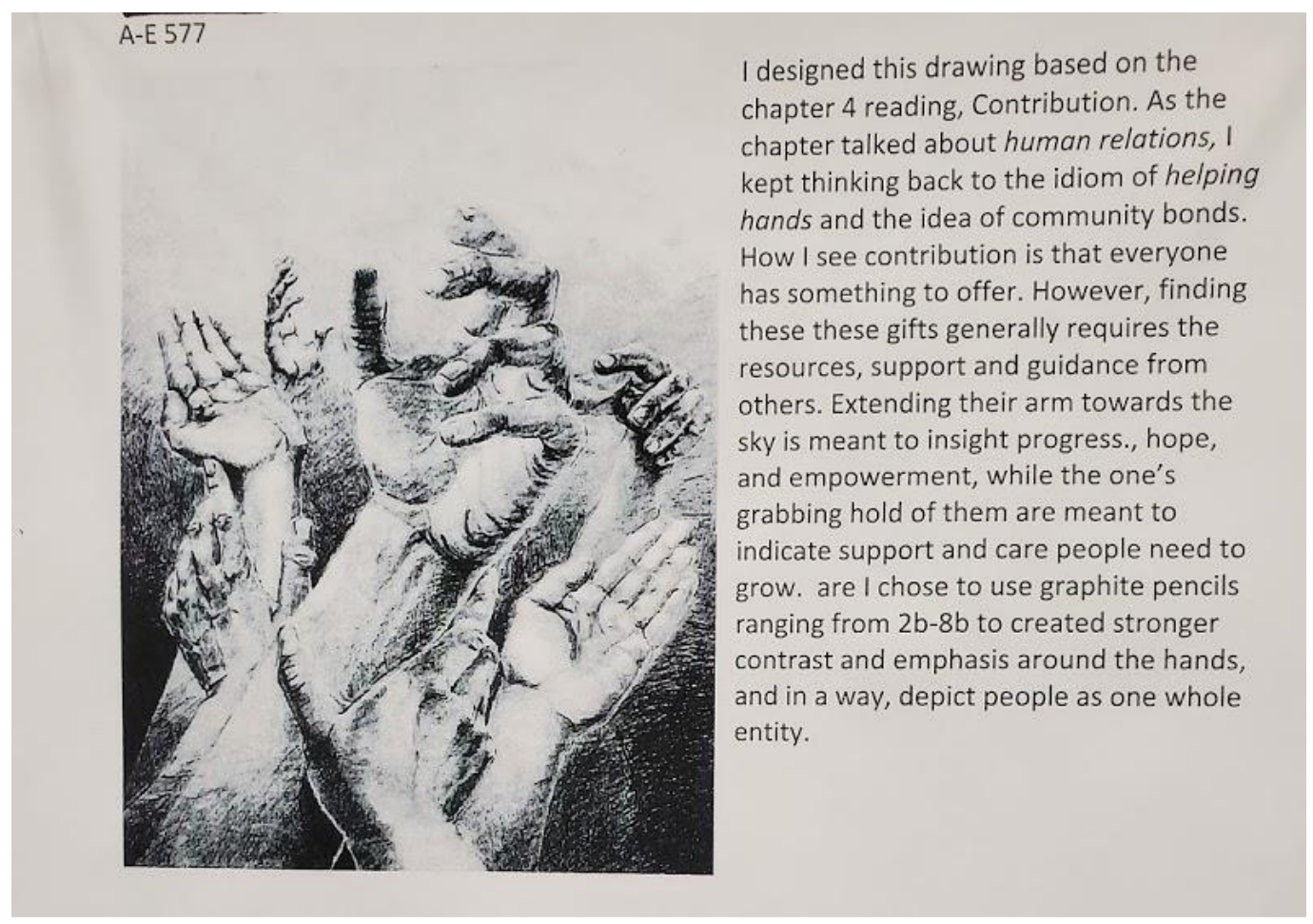




\section{Chapter 6: Media and Materials and Techniques}

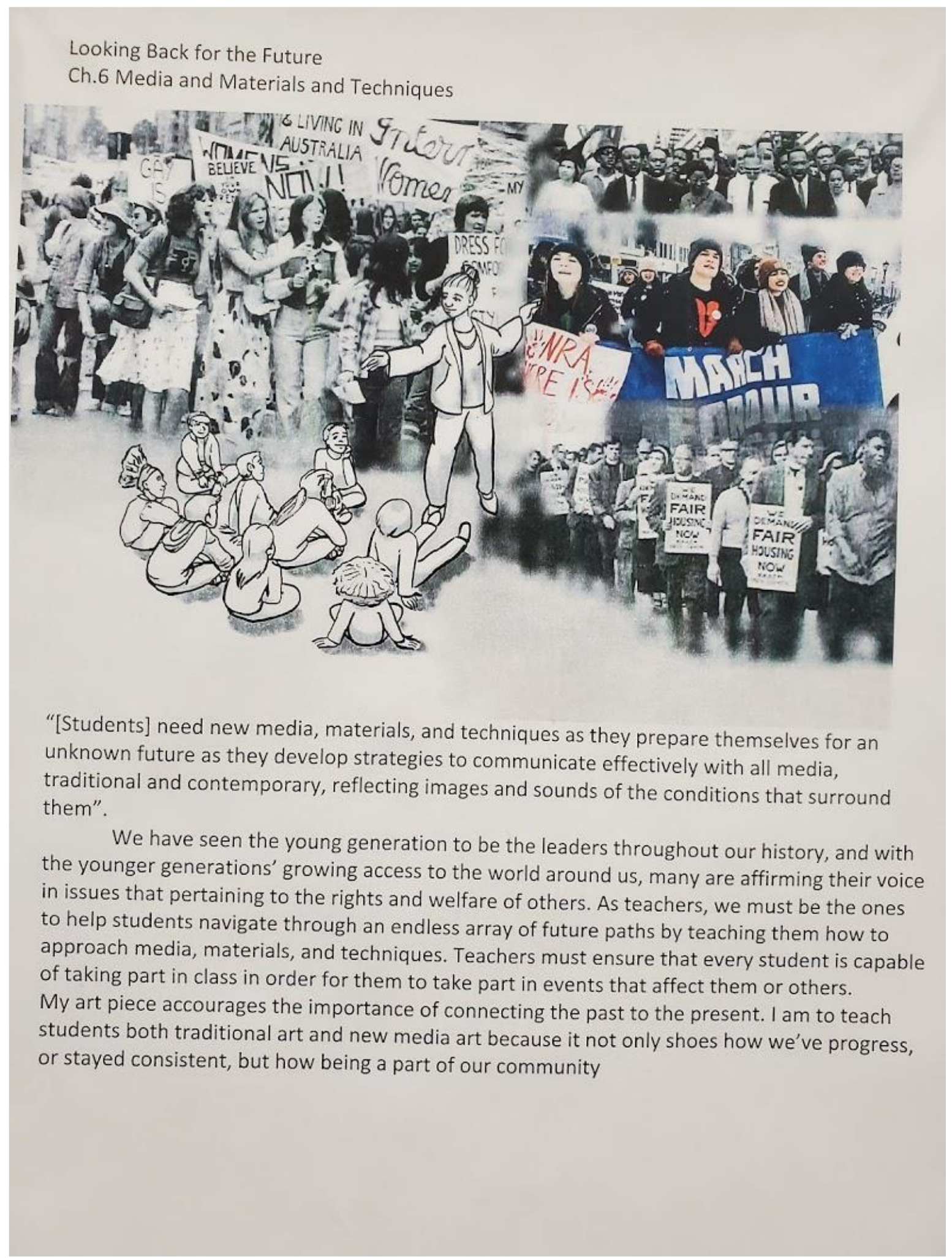




\section{Conclusion/Summary}

Elizabeth is a fictional name of a student who was in one of my classes and she wrote:

"Spirituality is cultivated through the study of humanities to expose the similarities of the human condition throughout people of all backgrounds. This spirituality through humanities creates an understanding and a level of connectedness to other human beings that will prevent the perpetuation of "othering" that plagues our society and instills each student with a responsibility to take care of themselves, others, and the environment. The chapter (Chapter 4 in Global Consciousness through the Arts: A Passport for Students and Teachers) also defines human rights and focuses heavily on current cultural events that shape our society including terrorism, police brutality, poverty, education, and the environment."

Improving the human condition requires us first to understand and to address the issues that impact each of us. Because of our perceived differences, conflicts are inevitable, they are a part of our lives, but it is incumbent on all of us to do our part to ameliorate them. Whether they know it or not, the above students are developing the knowledge and skills to ameliorate problems that could cause conflicts by finding their voice, making contributions to society, and learning to effectively communicate through the fast-moving technology platforms. Using the United States as an example of how unresolved conflicts can mushroom and pose existential threats to the advancement of the human condition is intended to suggest that if it is happening here in the US, it can and is happening all over the world where there are conflicts between races, genders, religious persuasions, individuals, groups, communities, and countries -China, Russia, Syria, etc. When given opportunities, each person will encounter issues affecting them, challenges they want to overcome, problems they want to solve and education through the arts can provide students these opportunities. Improving the human condition gives us hope for a better future and hope for a better future is dependent on how well educators do their jobs preparing students to be good citizens of the global community.

\section{References}

Hamid, M. (2017). Exit West. New York, NY: Riverhead Books.

https://www.essentialneed.org/water-poverty-facts https://www.ted.com/talks/ken_robinson_says_scho ols_kill_creativity

Richards, A. \& Willis, S. (2nd Edition) (2020). Global Consciousness through the Arts: A Passport for Students and Teachers. Dubuque, IA: Kendall Hunt Publishing Company.

Robinson, K. (2011). Out of Our Minds: Learning to be Creative. United Kingdom: Capstone Publishing Ltd.

Vander Zanden, J. W. (June - September 1959). The ideology of White Supremacy. Journal of History and Ideas, Volume 20 (3), 385-402. Pennsylvania: University of Pennsylvania Press. communicate. 5 